\section{Haematological changes in Bufo maculatus treated with sublethal concentrations of Cadmium}

\author{
Lawrence Ikechukwu Ezemonye, \\ Alex Ajeh Enuneku \\ Department of Animal and \\ Environmental Biology (AEB), \\ University of Benin, PMB, Benin, Nigeria
}

\section{Abstract}

Adult Bufo maculatus was exposed to sublethal cadmium concentrations of $0.25,0.50$, 1.00 and $2.00 \mathrm{mg} / \mathrm{L}$. The toxicant from which the cadmium concentrations were prepared was cadmium chloride $\left(\mathrm{CdCl}_{2} \cdot \mathrm{H}_{2} \mathrm{O}\right)$. There were three replicate tanks per treatment and three individuals per tank including control groups. The hematologic alterations based on the examination of blood indices during the 28 days of exposure showed that total erythrocyte count (TEC), hematocrit (Hct) and hemoglobin $(\mathrm{Hb})$ concentration decreased $(\mathrm{P}<0.05)$ relative to controls. The decline was concentration-dependent as concentration of cadmium increased. The decline in hemoglobin and hematocrit in the experimental organism could be due to a decrease in the synthesis or release of erythrocytes into the circulation or an increase in the rate of erythrocyte destruction inflicted by cadmium toxicity. There was significant $(\mathrm{P}<0.05)$ elevation in total leukocyte count (TLC) with increase in the concentration of cadmium. The increase in total leukocyte count observed in this study could be attributed to a stimulation of the immune system in response to tissue damage caused by cadmium toxicity. The study has shown that the exposure of the Bufo maculatus toad to cadmium can inflict alterations in the hematologic indices, which could induce unfavorable physiological changes in the amphibian, which may lead to death. There is, therefore, the need to protect amphibians in order to sustain the biodiversity in the Nigerian Niger Delta ecological zone.

\section{Introduction}

In the past few decades, scientists have reported global declines in amphibian populations worldwide. ${ }^{1-3}$ Heavy metal pollution has been implicated as one of the possible causes. Metal accumulation in the tissues of amphibians is dependent upon exposure concentra- tions, time, temperature, age of amphibian, interaction with other metals, metabolic activity and water chemistry [Enuneku AA, unpublished data].

Cadmium is a toxic heavy metal widely used in industrial processes like the production of nickel-cadmium batteries, as a stabilizer in PVC products, in metallic pipes, as a neutron absorber in nuclear power plants, and as a color pigment and an anticorrosive agent and in phosphate fertilizers. ${ }^{4}$ Dumping and incineration of cadmium polluted waste causes pollution of terrestrial and aquatic ecosystems where amphibians reside. Effluents from these activities are sources of cadmium in aquatic environments. ${ }^{5}$ These have predisposed animal and human populations to both subtle and direct exposure pathways with an attendant increase in cadmium related pathologies. ${ }^{6}$ Cadmium is one of the PBTs (persistent, bioaccumulative and toxic) chemicals identified as a primary toxicant. ${ }^{7}$ Cadmium is considered to have toxic effects on hematologic parameters, prostate, kidney, lungs and testes. ${ }^{8}$ Recent research findings reveal that the monitoring of environmental toxicants using biological organisms is more realistic than physico-chemical measures of concentrations in water, soil or sediment. Maheswaran et al. ${ }^{9}$ have reported that the main components of blood, i.e. hemoglobin concentration ( $\mathrm{Hb})$, total erythrocyte count (TEC), total leukocyte count (TLC) and hematocrit (Hct), have been used as indicators of heavy metal pollution in the aquatic environment.

This study was conducted to evaluate the toxicity of cadmium on the flat backed toad Bufo maculatus, native to the Niger Delta Region of Nigeria and other West African countries. This species was selected because it is ubiquitous, sensitive to heavy metals, and easy to handle and raise in the laboratory.

\section{Materials and Methods}

The initial mean weight of toads was $27.14 \pm 0.34 \mathrm{~g}$. There was no significant difference $(P>0.05)$ between the mean weights of toads used in the experiments. Because metabolic activity changes with size and affects the parameters to be measured, individuals of similar size were used..$^{10}$ The toads were acclimatized to laboratory conditions in dechlorinated tap water for two weeks prior to the assay in plastic tanks measuring $49 \mathrm{~cm} \times 29 \mathrm{~cm} \times 24 \mathrm{~cm}$. During acclimation, the mean values for the test water quality were: temperature $22 \pm 1^{\circ} \mathrm{C}$; $\mathrm{pH} 5.7 \pm 0.4$; dissolved oxygen $4.7 \pm 0.7 \mathrm{ppm}$ hardness $36 \pm 1.24 \mathrm{ppm}$. The toads were fed daily ad libitum with termites. Toads maintained a photoperiod of $10 \mathrm{~h}$ light, $14 \mathrm{~h}$ dark regime. Stock solutions of $\mathrm{CdCl}_{2} \cdot \mathrm{H}_{2} \mathrm{O}$ were pre-
Correspondence: Alex Ajeh Enuneku, Department of Animal and Environmental Biology (AEB), University of Benin, PMB 1145, Benin, Nigeria. Tel. +234.803.077.3314.

E-mail: lexadena@yahoo.com

Key words: hematologic parameters, toxicity, amphibian, cadmium.

Contributions: Both authors contributed to study design and concept, sublethal exposure, laboratory analysis, collation of results and statistical analysis. A greater part of the funds used was provided by the second author. Both authors wrote the manuscript and edited the final version.

Conflicts of interests: the authors declare no potential conflicts of interests.

Received for publication: 11 October 2011.

Revision received: 22 November 2011.

Accepted for publication: 22 November 2011.

This work is licensed under a Creative Commons Attribution NonCommercial 3.0 License (CC BYNC 3.0).

(C) Copyright L.I. Ezemonye and A.A. Enuneku, 2011 Licensee PAGEPress, Italy

Journal of Xenobiotics 2011; 1:e7

doi:10.4081/xeno.2011.e7

pared by dissolving toxicant in distilled water. Treatment concentrations were achieved by serial dilutions. ${ }^{3}$ The toxicant in the test chamber was completely renewed with fresh solution of the same concentration every $24 \mathrm{~h}$.

Four sublethal concentrations $(0.25,0.50$, 1.00 and $2.00 \mathrm{mg} / \mathrm{L}$ ) of cadmium were prepared and 3 toads were introduced in each concentration per tank. For this sublethal exposure, 3 replicates were used. The toads were fed with termites ad libitum as in controls. At the end of 28 days, toads were decapitated and blood collected by heart puncture by means of a hypodermic syringe and needle. The blood collected from the heart was transferred to ethylenediaminetetraacetic acid (EDTA) containers for hematologic analysis. ${ }^{11}$ The treatment and control blood samples were used to estimate the hematologic parameters.

EDTA was used as anticoagulant and noncoagulated blood was tested shortly after collection for Hb, TEC, TLC and Hct. Hb concentration was estimated as cyanomethemoglobin according to Ochei and Kolhakter. ${ }^{12}$ TEC and TLC were determined according to the classical method using the Neubauer hematocytometer. Hematocrit was determined using microhematocrit tubes and a hematocrit centrifuge (Juan Model A 13). Blood was centrifuged at $1200 \times \mathrm{g}$ for $5 \mathrm{~min}$ and the hematocrit value was obtained. ${ }^{13}$ 


\section{Statistical Analysis}

Data were analyzed by one-way analysis of variance (ANOVA) followed by Duncan's Multisample Range post hoc test using SPSS 15 software (SPSS Inc. Chicago, USA). $\mathrm{P}<0.05$ was considered level of statistical significance.

\section{Results}

There was no significant difference in water quality parameters $(\mathrm{pH}$, temperature, dissolved oxygen, hardness and turbidity) monitored during the exposure periods for sublethal assays between various concentrations of the heavy metal and the control groups, or within concentrations $(\mathrm{P}>0.05)$. The parameters were almost uniform throughout the study, irrespective of the treatment or duration.

The effects of cadmium on hematologic parameters are presented in Figures 1-4. The mean values of hematocrit, total erythrocyte count, total leukocyte count and hemoglobin were seen to increase with an increase in concentration of cadmium compared to control groups. However, total leukocyte count decreased as concentration of heavy metal increased at levels of $\mathrm{P}<0.05$.

\section{Discussion}

In this study, the administration of cadmium to $B$. maculatus induced a reduciton in total erythrocyte counts, hematocrit and hemoglobin levels with an increase in the concentration of cadmium. The observed decrease in these blood indices is indicative of cadmiuminduced anemia and is consistent with previous studies of anemia in fish, rats and rabbits exposed to cadmium, mercury, lead, nickel, copper and zinc. ${ }^{14-16}$ Various mechanisms have been proposed for cadmium-induced anaemia. These include iron deficiency anemia due to competition of cadmium with iron in the iron transfer system of the intestinal mucosa, hypoplastic anemia derived from the inhibitory effect of cadmium on the growth of erythroid progenitor cells ${ }^{17}$ or bone marrow cells, ${ }^{18}$ and hemolytic amemia due to red cell sequestration in the spleen. ${ }^{19}$

Lowe-Jinde and $\mathrm{Niimi}^{20}$ observed a reduction in the number of erythroblasts-proerythrocytes in goldfish, Carassius auratus and rainbow trout Salmo gairdneri exposed to cadmium. They suggested that cadmium caused a reduction in erithropoeisis and impeded the formation of red blood cells. Again the accumulation of cadmium in various organs particularly the kidney and liver has been observed ${ }^{21-23}$ and it is conceivable that the activity of these hematopoietic tissues may be suppressed or compromised. However, it cannot be ruled out that a decline in hemoglobin and hematocrit in the toad, Bufo maculatus could be due to a decrease in the synthesis or release of erythrocytes into the circulation or an increase in the rate of erythrocyte destruction.

The increase in total leukocyte count observed in this study could be attributed to a stimulation of the immune system in response to tissue damage caused by cadmium toxicity. Tissue damage or injury could induce stimulation of the immune system manifested by an increase in lymphocytes. ${ }^{24}$ Various authors have reported an increase in leukocyte count due to heavy metal exposure in experimental organisms. Lowe-jinde and $\mathrm{Niimi}^{20}$ also reported that the rainbow trout exposed to $4 \mu \mathrm{g} / \mathrm{L}$ cadmium sulphate for 14 days had an increase in leukocyte production when compared to the control fish but that after 96 days they showed

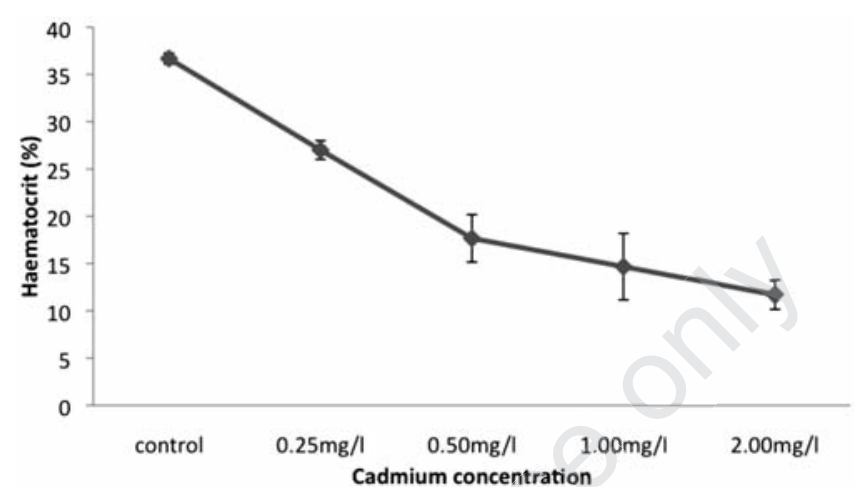

Figure 1. Variation in hematocrit in B. maculatus exposed to cadmium. Values are mean \pm stand ard deviation $(n=9)$.

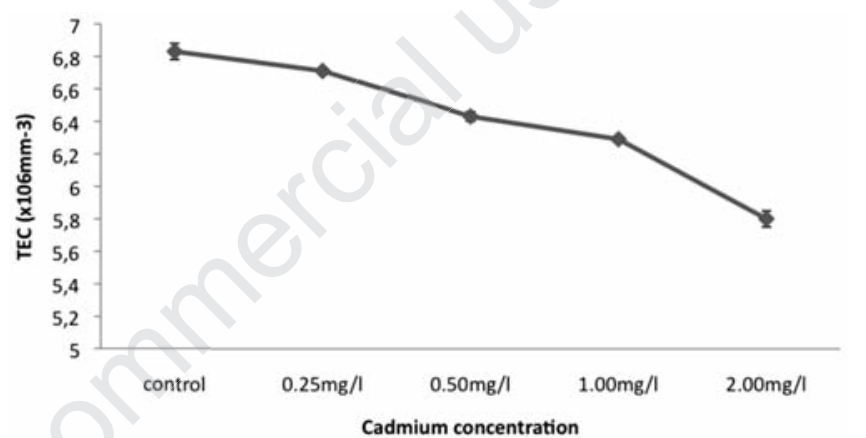

Figure 2. Variation in total erythrocyte count in $B$. maculatus exposed to cadmium. Values are mean \pm standard deviation $(\mathbf{n}=9)$.

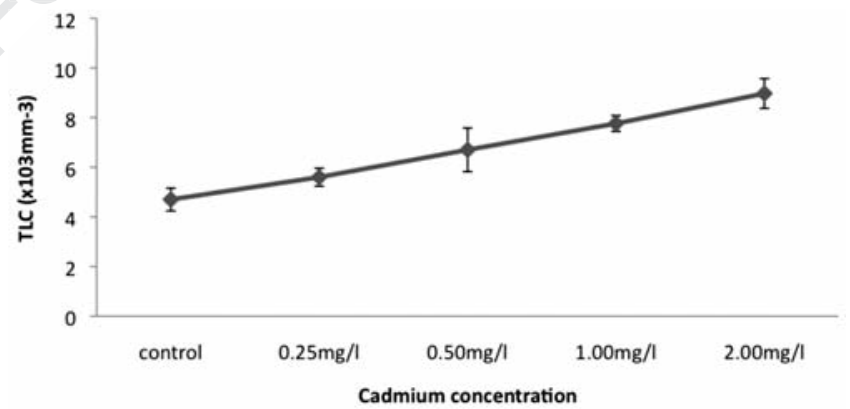

Figure 3. Variation in total leukocyte count in B. maculatus exposed to cadmium. Values are mean \pm standard deviation $(n=9)$.

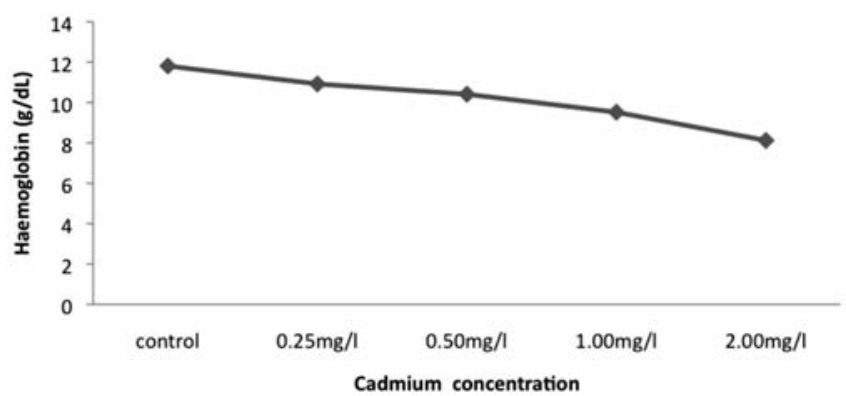

Figure 4. Variation in hemoglobin concentration in B. maculatus exposed to cadmium. Values are mean \pm standard deviation $(n=9)$. 
a significant decrease.

The release of cadmium into the environment could possibly affect the wellbeing of the organism as well as result in a decline in the numbers of these very sensitive anurans that make a significant contribution to the food chain.

\section{References}

1. Houlahan JE, Findlay CS, Schmidt BR, Kuzmin SL. Quantitative evidence for global amphibian declines. Nature 2000; 404:752-5.

2. Edginton AA, Sheridan PM, Stephensen, $\mathrm{GR}$, et al. Comparative effects of $\mathrm{pH}$ and vision herbicide on two life stages of four anuran amphibian species. Environ Toxicol Chem 2004;23:815-22.

3. Ezemonye L, Enuneku A. Stage-dependent acute toxicity of exposure of Bufo maculatus and Ptychadena bibroni tadpoles to cadmium (Cd2+). J Appl Sci Technol 2006; 11:78-82.

4. Ezemonye L, Enuneku A. Biochemical changes in the toad, Bufo maculatus treated with sub lethal concentrations of cadmium. World J Biol Res 2011;4 :15-20.

5. Kaoud HA, Zaki MM, El-Dashan AR, et al. Amelioration of toxic effects of cadmium exposure in Nile Tilapia, Oreochromis niloticus by using Lemna gibba L. Life Sci J 2011;8:1.

6. Satarug S, Moore, MR. Adverse health effects of chronic exposure to low-level cadmium in foodstuffs and cigarette smoke. Environ Health Perspect 2004;112: 1099-103.

7. EPA. Technical fact sheet for cadmium.
EPA905-F-00-028. United States Environmental Protection Agency, Region 5, Wastes, Pesticides and Toxics. Chicago, III, USA, 2000.

8. Tiwari M, Nagpure NS, Saksena DN, et al. Evaluation of acute toxicity levels and ethological responses under heavy metal cadmium exposure in freshwater Teleost, Channa punctata (Bloch). Int J Aquat Sci 2011;2:11.

9. Maheswaran R, Devapaul A, Muralidharan $\mathrm{S}$, et al. Haematological studies of freshwater fish Clarias batrachus (L) exposed to mercuric chloride. International $\mathrm{J}$ Intergr Biol 2008;2:49-54.

10. Canli M, Furness RW. Toxicity of heavy metals dissolved in sea water and influences of sex and size on metal accumulation and tissue distribution in the Norway lobster Nephrops norvegicus. Mar Environ Res 1993;36:217-36.

11. Mgbenka B0, Oluah NS. Effects of Gammalin 20 (Lindane) on differential whole blood cell counts of the African Catfish Clarias albopunctatus. Bull Environ Contam Toxicol 2003;71:248-54.

12. Ochei 0, Kolhatker A. Medical Laboratory Science, Theory and practice. New Delhi: Tata McGraw-Hill Publishing Company Ltd.; 2000. pp. 275-7.

13. Cheesbrough M. District Laboratory practices for tropical countries. Part 2. Cambridge, UK: Cambridge University Press; 2002.

14. Sjobeck ML, Haux H, Larsson A, Lithner G. Biochemical and haematological studies on perch Perca fluvaital from cadmiumcontaminated river Eman. Ecotox Environ Saf 1984;8:303-12.

15. Nanda P, Behera MK. Nickel induced changes in some haematological parame- ters of a catfish Heteropneustes fossilis (Bloch). Environ Ecol 1996;14:82-5.

16. Bersenyi A, Fekete Z, Berta E. Effect of ingested heavy metals $(\mathrm{Cd}, \mathrm{Pb}$ and $\mathrm{Hg}$ ) on haematology and serum biochemistry in rabbits. Acta Vet Hung 2003;51:297-394.

17. Lutton JD, Ibraham NG, Friendland M, Levere RD. The toxic effects of heavy metals on rat bone marrow invitro erythropoiesis: protectine role of hemin and zinc. Environ Res 1984;35:97-103.

18. Hays EF, Margarette N. Long term oral cadmium produces bone marrow hypoplasia in mice. Exp Hematol 1985;13:229-34.

19. Kunimoto M, Miura T. Density increament and decreased survival of rat red blood cells induced by cadmium. Environ Res 1986; 39:86-95.

20. Lowe-Jinde J, Niimi D. Haematological characteristics of rainbow trout Salmo gairdneri (Richardson), in response to cadmium exposure. Bull Environ Contam Toxicol 1986;37:375-81.

21. Kumada H, Kimur S, Yokoto M. Accumulation and biological effects of cadmium in rainbow trout. Bull Jpn Sci Fish 1980;40:97-103.

22. Giles MA. Accumulaion of cadmium by rainbow trout Salmo gairdneri during extended exposure. Can J Fish Aquat Sci 1988;45:1045-53.

23. Clinier DC, Ramel MA, Faure R, Garin D. Cadmium bioaccumulation in carp, Cyprinus carpio tissues during long-term high exposure analysis by inductively coupled plasma mass spectrometry. Ecotoxicol Environ Saf 1997;38:137-43.

24. Gill TS, Pant JC. Erythrocytic and leucocytic responses to cadmium poisoning to freshwater fish Puntius conchonius. Ham Environ Res 1985;3:372-3. 